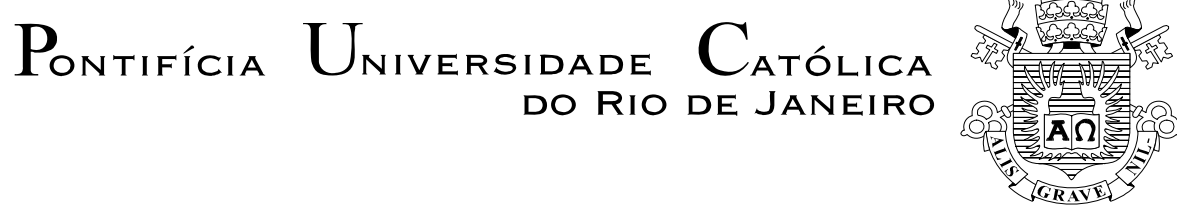

Davi Oliveira do Nascimento

Produção e produtividade lexical em José Cândido de

Carvalho

Dissertação de Mestrado

Dissertação de Mestrado apresentada como requisito parcial para obtenção do grau de Mestre em Letras do Departamento de Letras da PUC-Rio como parte dos requisitos parciais para obtenção do título de Mestre em Letras.

Orientadora: Profa. Margarida Maria de Paula Basilio 


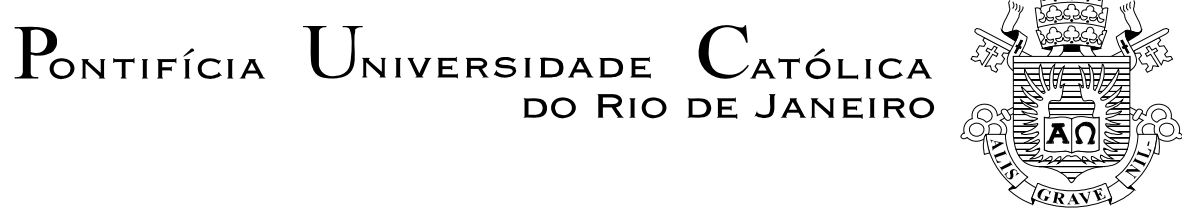

Davi Oliveira do Nascimento

\title{
Produção e produtividade lexical em José Cândido de \\ Carvalho
}

\begin{abstract}
Dissertação apresentada como requisito parcial para a obtenção do grau de Mestre pelo Programa de PósGraduação em Letras do Departamento de Letras do Centro de Teologia e Ciências Humanas da PUC-Rio. Aprovada pela Comissão Examinadora abaixo assinada:
\end{abstract}

Profa. Margarida Maria de Paula Basilio

Orientadora

Departamento de Letras - PUC-Rio

Profa. Maria Paula Frota Departamento de Letras - PUC-Rio

Prof. Carlos Alexandre Victorio Gonçalves

UFRJ

Prof. Paulo Fernando Carneiro de Andrade

Coordenador Setorial do Centro de Teologia

e Ciências Humanas - PUC-Rio

Rio de Janeiro, de de 
Todos os direitos reservados. É proibida a reprodução total ou parcial do trabalho sem a autorização da universidade, da autora e da orientadora.

\section{Davi Oliveira do Nascimento}

Ficha Catalográfica

Nascimento, Davi Oliveira do

Produção e produtividade lexical em José Cândido de Carvalho / Davi Oliveira do Nascimento ; orientadora: Margarida Maria de Paula Basílio. - 2009.

72 f. ; $30 \mathrm{~cm}$

Dissertação (Mestrado em Letras) - Pontifícia Universidade Católica do Rio de Janeiro, Rio de Janeiro, 2009

Inclui bibliografia

1. Letras - Teses. 2. Morfologia. 3. Léxico. 4. Formação de palavras. 5. Produtividade/produção. 6. Formações expressivas. 7. Inovações lexicais. I. Basílio, Margarida Maria de Paula. II. Pontifícia Universidade Católica do Rio de Janeiro. Departamento de Letras. III. Título. 


\section{Resumo}

Nascimento, Davi Oliveira do; Basilio, Margarida Maria de Paula (Orientadora). Produção e produtividade lexical em José Cândido de Carvalho. Rio de Janeiro, 2009. 72p. Dissertação de Mestrado Departamento de Letras. Pontifícia Universidade Católica do Rio de Janeiro

Este trabalho constitui-se num estudo morfológico sobre a questão produtividade / produção de padrões lexicais em textos literários, com o objetivo de sustentar a hipótese de que tais obras apresentam condições de produção especiais em relação a determinados padrões morfológicos de formação. A base de investigação é a obra “O Coronel e o Lobisomem”, de José Candido de Carvalho, já conhecida por seu teor de inovação lexical. São eleitas para análise as sufixações com -ão e -oso e a prefixação com des-, formações morfológicas que se constituem em potenciais processos de inovação lexical. Sugere-se que a utilização de tais padrões na obra não é fortuita, já que parecem representar iconicamente o discurso hiperbólico do personagem principal. De início, apresenta-se uma visão geral da morfologia lexical, quanto a seu tratamento tradicional e em relação a contribuições mais recentes, focalizando-se especialmente a questão produtividade/produção. Procede-se depois à apreciação do tratamento dado pelos estudiosos do português sobre os formativos com -ão, oso e des-. Em seguida, são analisadas as formações encontradas na obra "O Coronel e o Lobisomem”. Finalmente, são apresentadas as conclusões sobre o uso que o autor faz dos padrões de formação em sua obra, os quais refletem o discurso do personagem principal, com vistas a afirmar a relevância da análise das condições de produção, ao lado da questão da produtividade, para um melhor conhecimento do léxico do português.

\section{Palavras-chave}

Morfologia, léxico, formação de palavras, produtividade/produção, formações expressivas, inovações lexicais. 


\section{Abstract}

Nascimento, Davi Oliveira do; Basilio, Margarida Maria de Paula (Advisor). Production and lexical productivity in José Cândido de Carvalho. Rio de Janeiro, 2009. 72p. MSc Dissertation - Departamento de Letras, Pontifícia Universidade Católica do Rio de Janeiro.

This work is a morphologic study on the issue of lexical productivity and production in literary texts. Its main goal is to support the hypothesis that literary works present special conditions for the use of morphological formation patterns. Our investigation is based on the novel "The Colonel and the Werewolf" by Jose Candido de Carvalho, a work which is known for its lexical innovations. The suffixes -ão and -oso, as well as the prefix des- were chosen for our analysis, as they are the preferred morphological elements for lexical innovation in Carvalhos's work. Our results suggest that the use of these morphological patterns in the work is not fortuitous; in fact, they seem to iconically represent the hyperbolic discourse of the main character of the novel. We initially present an overview of lexical morphology, which includes both traditional approaches and recent contributions; the main focus will be on the productivity/production issue. Then, we approach the description of the suffixes -ão and -oso and the prefix desin Portuguese. Next, the lexical constructions with these elements occurring in the book "The Colonel and the Werewolf" are analyzed. We conclude showing that the author uses morphological patterns to reinforce the discourse of the main character of the novel. This analysis shows the relevance of the study of production conditions, in addition to productivity, for a deeper understanding of the lexicon in Brazilian Portuguese

\section{Keywords}

Morphology, lexicon, word formation, productivity/production, expressive formations, lexical innovation. 


\section{Sumário}

1. Introdução

1.1. O autor e a obra

1.2. Procedimentos metodológicos 9

2. A morfologia lexical $\quad 11$

2.1. Diferentes abordagens da morfologia lexical 11

2.2. A formação de novas palavras $\quad 12$

2.3. A competência lexical 13

2.4. As condições de produção e de produtividade lexical 15

3. Contribuições da morfologia gerativa e da gramática tradicional para $\begin{array}{ll}\text { os estudos sobre derivações prefixal e sufixal } & 18\end{array}$

3.1. Noções de sufixo e de prefixo conforme a morfologia gerativa 18

3.2. Noções de sufixo e de prefixo conforme a tradição gramatical 20

3.3. O prefixo des- 22

3.4. Sobre sufixação 25

3.5. O sufixo -oso 27

3.6. O sufixo -ão 28

4. Análise do corpus eleito 32

4.1. As formações com des-

4.1.1. As formações com bases susbtantivas $\quad 32$

4.1.2. As formações com bases adjetivas 36

4.1.3. As formações com bases verbais $\quad 41$

4.2. As formações com -oso $\quad 44$

4.2.1. As formações com bases substantivas $\quad 44$

4.2.2. As formações com bases adjetivas $\quad 48$

4.2.3. As formações com bases verbais $\quad 51$

4.3. As formações com -ão

4.3.1. As formações com bases substantivas

4.3.2. As formações com bases adjetivas $\quad 58$

4.4. Casos especiais 61

5. Conclusões $\quad 62$

5.1. A motivação icônica $\quad 62$

5.2. Produtividade e produção $\quad 65$

6. Referências bibliográficas $\quad 66$

$\begin{array}{ll}\text { 7. Apêndice } & 70\end{array}$ 